DOI: https://doi.org/10.34069/AI/2021.47.11.5

How to Cite:

Reznik, O., Utkina, M., Starinskyi, M., Isaieva, N., \& Kysil, L. (2021). Judicial protection service and its analogues: a comparative legal research. Amazonia Investiga, 10(47), 47-53. https://doi.org/10.34069/AI/2021.47.11.5

\title{
Judicial protection service and its analogues: a comparative legal research
}

\section{Служба судової охорони та її аналоги: порівняльно-правове дослідження}

Received: September 29, 2021

\section{Abstract}

The article's relevance is because the Judicial Protection Service is a relatively new institution, the creation of which was completed last year. However, analogs of such a service operate successfully in different countries (in particular, the United States, Canada). Effective maintenance of law and order during the court hearing is one of the main elements of the reform processes of the judicial system of Ukraine, which must directly meet European standards. Because of this, the issue of research of this institution in Ukraine and the possibility of implementing best practices in the functioning of its counterparts in foreign countries is relevant. The purpose of the study was to determine the characteristics of the judicial protection service and its analogs in different countries. The object of the study is the public relations that arise in the field of security and independence of the judiciary. The subject of the study is the principles of functioning of the judicial protection service and its analogs. The
Accepted: November 10, 2021

Written by:

Oleg Reznik ${ }^{19}$

https://orcid.org/0000-0003-4569-8863

Web of Science researcher code: AAJ-3122-2020

Maryna Utkina ${ }^{20}$

https://orcid.org/0000-0003-4569-8863

Web of Science researcher code: ABF-9368-2020

Mykola Starinskyi ${ }^{21}$

https://orcid.org/0000-0003-2661-5639

Web of Science researcher code: P-2393-2014

Nataliia Isaieva ${ }^{22}$

https://orcid.org/0000-0002-9716-9472

Liudmyla Kysil ${ }^{23}$

https://orcid.org/0000-0001-7986-0967

\section{Анотація}

Актуальність статті обумовлена тим, що Служба судової охорони є відносно новою інституцією, створення якої завершилось минулого року. Проте, аналоги такої служби успішно функціонують у різних країнах (зокрема, США, Канада). Ефективне забезпечення правопорядку під час проведення судового засідання виступає одним із головних елементів реформаційних процесів судової системи України, що мають безпосередньо відповідати європейським стандартам. Зважаючи на це, актуалізується питання дослідження даної інституції в Україні та можливості імплементації кращих практик функціонування iї аналогів у зарубіжних країнах. Метою дослідження стало визначення особливостей діяльності служби судової охорони та іï аналогів у piзних країнах. Об'єктом дослідження $\epsilon$ суспільні відносини, що виникають у сфері забезпечення безпеки і незалежності суду. Предметом дослідження $є$ засади

\footnotetext{
${ }^{19}$ Doctor of Legal Sciences, Associate Professor, Department of Administrative, Economic Law and Financial and Economic Security, Sumy State University, Ukraine.

${ }^{20} \mathrm{PhD}$ in Law, Senior Lecturer, Department of Criminal Legal Disciplines and Procedure, Sumy State University, Ukraine.

${ }^{21}$ Doctor of Legal Sciences, Professor, Department of Administrative, Economic Law and Financial and Economic Security, Sumy State University, Ukraine.

${ }^{22} \mathrm{PhD}$ in Law, Associate Professor, Senior Scientific Reseacher V.M. Koretsky Institute of State and Law of National Academy of Sciences of Ukraine.

${ }^{23} \mathrm{PhD}$ in Law, Associate Professor, Senior Scientific Reseacher V.M. Koretsky Institute of State and Law of National Academy of Sciences of Ukraine.
} 
methodological basis of the study is a set of general and unique methods of cognition, in particular: dialectical, historical, descriptive, methodology of scientific analysis, and generalization-comparative law, structuralfunctional and analytical. Analyzing the experience of foreign countries in organizing the activities of similar institutions of the Judicial Protection Service, it was emphasized the high level of trust of judges in such judicial protection services and the close cooperation of the latter with law enforcement agencies. The authors of the article also emphasize that the formation and operation of institutions as the Judicial Protection Service directly depend on financial support, organizational issues, and personnel policy.

Keywords: the rule of law, protection, judiciary, Judicial Protection Service, judicial protection.

\section{Introduction}

The great judiciary reforms in Ukraine brought significant changes to its organization (Prytyka, \& Kravtsov, 2019). To comply with European standards, it was necessary to ensure effective law and order during the trial. Thus, it is one of the main elements of the reform processes of the judicial system of Ukraine.

The protection of judicial institutions and judges themselves is relevant in the context of the need to ensure the stability of the judiciary. This is because the destabilization of the judiciary poses, first of all, a threat to the establishment of the fundamental principle of the rule of law, undermines the rule of law in the state, and causes irreparable damage to the authority of any country in the international arena. The paper emphasizes the need to protect judicial institutions and judges, as the lack of such protection leads to free access to the premises of persons who interfere with the work of judges, violate public order, and disrupt court hearings. As a result, there is a violation of the human right to go to court to protect the rights and freedoms, as well as a clear threat to the life or health of judges and court staff. However, this is a violation because one of the fundamental rights of every person is the right of a person to a fair trial (Svyda, Kovalchuk, Torbas, Melnychuk, \& Kytaika, 2019). функціонування служби судової охорони та іiі аналогів. Методологічну основу дослідження становить сукупність загальних та спеціальних методів пізнання, зокрема: діалектичний, історичний, описовий, метод наукового аналізу та узагальнення. порівняльно-правовий, структурнофункціональний та аналітичний. Проаналізувавши досвід зарубіжних країн щодо організації діяльності інституційаналогів Служби судової охорони, було наголошено на високому рівні довіри суддів до таких служб судової охорони, а також тісній взаємодії останніх із правоохоронними органами. Автори статті наголосити також i на тому, що становлення та діяльність інституцій як Служба судова охорона напряму залежать від фінансового забезпечення, організаційних питань, а також - кадрової політики.

Ключові слова: верховенство права, охорона, судова влада, служба судової охорони, судова охорона.

Moreover, it should be noted that the first origins of this fundamental human right were enshrined in the Grand Charter of Liberties in 1215 (Holt, 2015). Therefore, research on the activity of the Judicial Protection Service is essential and relevant. The study aimed to determine the features of the Judicial Protection Service and its analogs in different countries. The object of research is public relations that arise in the security and independence of the judiciary. The subject of the study is the principles of functioning of the judicial protection service and its analogs.

The study's theoretical framework is the scientific works of domestic and foreign scientists who reveal the essence of the Judicial Protection Services and its analogs and an adequate level of judicial security in general. Establishing and successfully ensuring public order during the court hearings is possible only when several essential components are observed at the appropriate level. These include effective methods and ways of detecting offenses during the court hearings and successful counteraction to such phenomena. In addition, according to the experience of developed countries, a clear and understandable system of inevitable liability of offenders should be established (Dzhafarova, Ivanova, Zahorodniuk, \& Zaiets, 2020). The authors studied the general provisions on ensuring public order during the court hearings in 


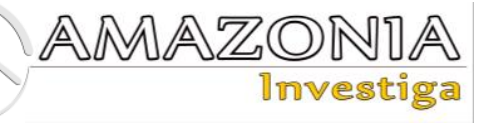

the context of reforming the judicial system of Ukraine. At the same time, Lorraine H. Tong (2008) outlined in the Report for Congress issues on judicial security responsibilities and jurisdiction. The author stressed that to protect the judiciary, the principal entities communicate and coordinate at the national and district levels.

\section{Methodology}

Methods and techniques of scientific cognition, which are defined following the study's purpose, constitute the article's methodological basis. The work combines general scientific and unique methods, which in complex application allowed to achieve positive research results. The authors used the analytical method during the analysis and substantiation of some theoretical authors' positions, for example, the stages of development of the Judicial Protection Service. Dialectical (to determine the functions of the given institution); historical method (to study the process of formation of the system of protection services in the world in general and in Ukraine in particular), descriptive method (to reveal some concepts, conduct an available description of the elements of the judicial protection). In addition to general scientific methods, we used the comparativelegal method (to compare the Judicial Protection Service in Ukraine and its analogs in foreign countries).

\section{Results and discussion}

«Court security» embraces a wide range of issues. It stretches from physical protection of judges to education and workplace violence to data integrity to architecture (Zaruba, 2007). Effective maintenance of law and order during the court hearing is one of the main elements of the reform processes of the judicial system of Ukraine, which must directly meet European standards. Such state-building approaches emphasize the youth and prospects of our state. One of the examples of constant reform activity and improvement of the administrative and legal status of a state institution is the Judicial Protection Service.

The lack of protection of judicial institutions has become relevant since the liquidation in Ukraine in 2015 of special units of the Ministry of Internal Affairs "Griffon". As a result, the liquidation of such structures has led to the fact that persons who could interfere with the work of judges, disturb public order, disrupt court hearings, have free access to court premises. As a result, there was a case in the Nikopol City District Court of the Dnipropetrovsk region, which led to the death of two and the injury of ten people (Verkhnorogachytsky District Court of Kherson Oblast (region), 2017). There have been cases where courts have been mined, judges are afraid to take to the streets, overly emotional visitors damage court property, destroy judges' personal belongings, disrupt courtrooms or shoot at the courtroom.

Or in the U.S.A., for example, the importance of judicial security was underscored by the murders of family members of a Chicago federal judge on February 28, 2005, and the killings less than two weeks later of a state judge, a court reporter, and a sheriff's deputy in an Atlanta courthouse. Shortly after these incidents, the House and the Senate held hearings, and legislation was introduced to (among other things) improve courtroom security for judicial officers; safeguard judges and their families at home; restrict postings of personal information about judicial officers and their families on the Internet; extend or make permanent the authority to redact certain information from judicial officers, judicial employees, and their families' financial disclosure forms; and increase penalties for attacks against them and other law enforcement personnel (Tong, 2008).

It is the above events that lead to the destabilization of the judiciary, threaten the establishment of the rule of law in any country, undermine the foundations of law and order, cause irreparable damage to the authority of the state in the international arena (Zuieva, \& Prystup, 2019). As a result of such events, violations of the human right to go to court to protect the rights and liberties should also be identified and, to some extent, a real threat to the health or even life of judges, staff, and visitors court.

In turn, the particular unit "Griffon", which was supposed to protect ships, could not guarantee it $100 \%$. In particular, the protection of appellate and district courts, located in oblast centers, was mainly carried out, and special police units did not guard most local, district, and city courts of the first level. Some researchers emphasized that the situation was saved because, in most cases, criminal cases were heard in local courts, and therefore - in the courts were convoy police officers who guarded detainees and took to a court trial. Because of this, there was an unspoken agreement between the Council of Judges of Ukraine and the National Police on the exercise of the protective function of the courts during the consideration of, particularly highprofile cases. The current situation needs to be 
addressed urgently. Because of the above, this became a precondition in Ukraine for creating a particular institution that would ensure law and order and protect judges. A unique body was made - the Judicial Protection Service. In particular, in the spring of 2019, the High Council of Justice approved the Regulations on the Judicial Protection Service and appointed the former Deputy Commander of the National Guard of Ukraine, Major General Valery Bondar, who won the competition for the position of head of this service (Ukrinform, 2019). From this point, you can start counting from the moment of the active process of creating this institution.

The need to create this state agency is since the Art. 160 of the Law of Ukraine "On the Judicial System and the Status of Judges" (Law of Ukraine No. 1402-VIII, 2016) provides that keeping public order in court, cessation of contempt of court, as well as protection of court premises, agencies, and institutions of justice, functions concerning the state security of personal security of judges and members of their families, court employees, the safety of court participants is ensured by the Judicial Protection Service (Dzhafarova, Ivanova, Zahorodniuk, \& Zaiets, 2020).

However, on August 5, 2018, amendments to the Law of Ukraine "On the Judiciary and the Status of Judges" came into force in the context of the adoption of the Law of Ukraine "On the Supreme Anti-Corruption Court" (Law of Ukraine No. 2447-VIII, 2018). The latter stated that the Judicial Protection Service provides the protection of a judge of the Supreme AntiCorruption Court, members of his family, and the safety of a judge's home. In case of threat to the life or health of a judge of the High AntiCorruption Court, members of his family, at the request of the judge, the Judicial Protection Service shall ensure the temporary placement of such persons in places that guarantee their safety; the office premises of the High Anti-Corruption Court are equipped with modern security measures that guarantee the personal safety of judges, preservation of the documentation of the High Anti-Corruption Court, and the prevention of illegal entry into the premises of this court.

In particular, the Law of Ukraine "On the Judiciary and the Status of Judges" was substantially amended: instead of one article in the Law, namely 160, which referred to "Ensuring the protection and maintenance of public order in courts", a whole Chapter 4 was adopted. Following it, the issue of ensuring the protection and maintenance of public order in the courts is regulated by the Judicial Protection Service.

Because of the above, the establishment of this service is a priority and highly relevant because of the frequent and unprecedented cases of damage to court property, encroachment on the physical safety of litigants, staff, and judges.

The Judicial Security Service - is a state agency that, through its units, keeps public order in court; prevents manifestations of contempt of court and stops such expressions; protects the premises and other property of courts, judicial authorities; provides state protection of judges, court staff and their families, as well as guarantees the safety of participants in court proceedings (Law of Ukraine No. 1402-VIII, 2016). This institution has gone from a particular unit in the structure of the public security police, a specific branch of the judicial authority "Griffon" to an independent state body in the justice system to ensure the protection and maintenance of public order in the courts.

According to the Regulations on the Judicial Protection Service (Decision No. 1051/0/15/1519, 2019), the Judicial Protection Service is accountable to the High Council of Justice and under the control of the State Judicial Administration of Ukraine. The main tasks of the Judicial Protection Service were identified, namely:

1) maintenance of public order in court;

2) termination of contempt of court;

3) protection of court premises, bodies, and institutions of the justice system;

4) performing functions related to the state security of personal security of judges and members of their families, court employees;

5) ensuring the safety of participants in the trial in court.

In turn, in an interview, Andriy Ovsienko, the Head of the High Council of Justice, stressed out that: "The purpose of the Judicial Protection Service is not only to ensure the safety of courts but also to guarantee the safety of litigants". He also noted that the development of Ukrainian judicial protection was based on the experience of overcoming difficult situations of the Canadian Sheriff's Office. At the same time, the Service was created on the minimum regulatory framework, ensuring its effective operation required changes to existing legislation (In 2021, the Judicial Protection Service will take under the protection of all bodies and institutions of the justice system). 


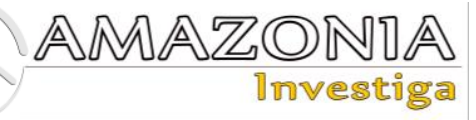

However, in connection with the functioning of the Judicial Protection Service, the question of the expediency of the existence of a court administrator service has arisen. Their primary tasks include the following:

1) ensuring compliance with the rules established by persons in court;

2) ensuring that the participants in the trial and other persons present in the courtroom comply with the instructions of the presiding judge at the hearing;

3) interaction with the Judicial Protection Service, the National Police of Ukraine, the National Guard of Ukraine regarding maintaining public order in the courtroom and the courtroom (Regulations No.815, 2017).

The courtroom should be equipped with alarm buttons, and in the event of an emergency, the response will be appropriate. The risk of an emergency has also been minimized. The Judicial Protection Service conducts a superficial inspection of persons entering the justice system's court premises, bodies, and institutions (visually inspecting and inspecting their belongings, holding persons on the surface with particular devices or means).

The Canadian model has been identified as one of the most influential and progressive court security systems (as an example, the British Columbia Sheriff's Office). It is based on a dynamic concept of comprehensive risk and threat assessment, which allows for effective operational planning and maintenance of the trial, measures to protect court infrastructure, and physical protection of persons. Another critical aspect in the organization and operation of the structures responsible for the protection of courts and judges in Canada is the extremely high level of trust of judges themselves in the judicial services and the close cooperation of the latter with the police. Of course, the judicial system of Canada differs significantly from the judicial system in Ukraine, which determines the specific structure, tasks, and powers of the judicial protection system in Ukraine.

As K. Savilova (2019) mentioned, the level of trust in judges in Canada remains relatively high, much higher than, for example, in lawyers. The office of the Commissioner, who manages the process of appointing judges of federal courts, contributes to the formation of a positive image of the judiciary, provides appropriate conditions for their work, taking care of security and safety, effective communication with the public. Critical criteria for selecting sheriffs are the ability to work in a team, initiative, decency, integrity, self-control, ability to manage conflicts, willingness to learn throughout life, commitment to the organization's interests. As a result of the interview, candidates may receive a preliminary job offer for further examination or placement.

At the same time, the United States Marshals Service, Judicial Security Division (JSD), is committed to protecting the judicial process by ensuring the safe and secure conduct of judicial proceedings and protecting federal judges, jurors, and other members of the federal judiciary. Protecting court officials and safeguarding the public is a responsibility that permits no errors. It is a comprehensive effort accomplished by anticipating and deterring threats to the judiciary and by continuously developing and employing innovative protective tactics (U.S. Marshals Service, 2021).

The tasks of the Service include ensuring the activities of federal courts, monitoring the execution of their sentences and decisions, tracing, arresting, and supervising the detention of federal criminals, the auction sale of confiscated property, and the fight against terrorism and riots. The first Congress created the posts of marshals and their deputies by the Judicial Act of 1789. This document determines that the function of marshals is to enforce laws. Thus, the United States Marshal Service is the oldest law enforcement agency that enforces federal laws. Marshals are responsible for finding fugitives, providing protection for the federal judiciary, transporting federal prisoners, protecting federal witnesses, guarding property confiscated by court order, and enforcing legal mandates and regulations issued by the authorities. Marshals carry out their activities within the entire country or a specific state or district, depending on the source. American marshals can recruit (recruit) citizens as assistants when needed. They cannot recruit soldiers on duty and in uniform, but they can if they are not on duty and in civilian clothes.

The establishment and development of the Ship Protection Service are rich in why it is more important to keep it in terms of financial security, protection, and management of food. Amid nonvirulent problems, Canadian Fakhivtsi called access to operational development information for the hourly prevention of threats. Important are strategic planning, balanced use of resources, emphasis on analysis, risk and threat assessment, the invisibility of protection (hidden bulletproof vests, weapons), and high-tech equipment. But 
no less important is respect for employees, considering their needs, opinions, and social protection. The main task is to make every effort to implement Canada's experience in organizing the defense of Ukrainian courts. This requires that the issue of court security becomes a priority of the state and society.

\section{Conclusions}

In conclusion, it should be noted that a powerful and at the same time cumbersome institution as the Judicial Protection Service has been created with a complex regulatory mechanism that duplicates the powers of the National Police, the National Guard, etc. At the same time, it does not directly provide for interaction between them, which requires a legislative solution. It is also advisable to reorganize the Service of Judicial Administrators, possibly by enrolling them in the staff of the Judicial Protection Service. The above does not indicate the need to amend the main legislative provisions governing the activities of the Judicial Protection Service to harmonize them with current regulations.

In general, it should be stressed out that the formation of the Service takes place in three stages. The first is the staffing of management bodies and units that will perform tasks related to the protection of the Supreme Anti-Corruption Court and other facilities, training and retraining of employees, security of $100 \%$ of facilities in Kyiv, Kyiv, and Vinnytsia regions, appellate and local courts in 16 regions of Ukraine. In the second stage, it was planned to ensure the protection of the remaining facilities (855), to supplement the staff of management bodies and units of rapid action and personal safety of judges and members of their families. The third stage is the completion of training programs, replenishment of operational and sudden action units, and completion of material and technical equipment of the Service.

\section{Bibliographic references}

Decision No. 1051/0/15/15-19 “On the Judicial protection Service", Review of the Bulletin of the VRU, of April 04, 2019. Retrieved from: https://zakon.rada.gov.ua/rada/show/v10519 10-19\#Text

Dzhafarova, M., Ivanova, H., Zahorodniuk, S., \& Zaiets, U. (2020). Ensuring Public Order during the Court Hearings in the Context of Reforming the Judicial System of Ukraine. Amazonia Investiga, 9(32), 10-17. https://doi.org/10.34069/AI/2020.32.08.1
Holt, J. C. (2015). Magna Carta. Cambridge: Cambridge University Press. Retrieved from: https://www.cambridge.org/core/books/mag nacarta/33A2EA4AA105FBEC9A43997CA21 27B15

Law of Ukraine No. 1402-VIII "On the Judicial System and the Status of Judges", Review of the Bulletin of the VRU, of June, 2016. Retrieved from: https://zakon.rada.gov.ua/laws/show/140219\#Text

Law of Ukraine No. 2447-VIII "On the Supreme Anti-Corruption Court". Review of the Bulletin of the VRU, of July 06, 2018. Retrieved from: https://zakon.rada.gov.ua/laws/show/244719\#Text

Prytyka, Y., \& Kravtsov, S. (2019). Review of Court Decisions: ¿Does Ukraine Guarantee the Right to a Fair Trial in Appeal?. Amazonia Investiga, 8 (23), 685-692. Retrieved from: https://amazoniainvestiga.info/index.php/am azonia/article/view/923

Regulations No.815 "On the Procedure for Establishing and Operating the Service of Court Administrators". Review of the Bulletin of the VRU, of June 06, 2017. Retrieved from: https://zakon.rada.gov.ua/rada/show/v08157 50-17\#Text

Savilova, K. (2019). Bodyguards of Themis. Law and Business, № 30 (1432). Retrieved from : http://www.vru.gov.ua/mass_media/1211

Svyda, T., Kovalchuk, I., Torbas, O., Melnychuk, Yu. \& Kytaika, O. (2019). The formation and current tendencies of international human rights protection concerning the right of a person to a fair trial, and their impact on Ukraine. Amazonia Investiga, 8 (23), 855-860. Retrieved from: https://amazoniainvestiga.info/index.php/am azonia/article/view/939

Tong, L. H. (2008). Judicial Security: Responsibilities and Current Issued. CRS Repost for Congress. Retrieved from: https://fas.org/sgp/crs/misc/RL33464.pdf

U.S. Marshals Service (2021). Judicial Security. Retrieved from: https://www.usmarshals.gov/judicial/

Ukrinform. (2019). The High Council of Justice has appointed Valery Bondar as the head of the Judicial Protection Service. Retrieved from: https://www.ukrinform.ua/rubricsociety/2664361-vrp-priznacila-valeriabondara-golovou-sluzbi-sudovoiohoroni.html 
Verkhnorogachytsky District Court of Kherson Oblast (region) (2017). Security of people in courts. Retrieved from: https://vr.ks.court.gov.ua/sud2105/prescentr/news/404250/

Zaruba, J.E. (2007). Courthouse Security-A Direction or a Destination? Justice System Journal, 28(1), 46-49. https://www.tandfonline.com/doi/abs/10.108 0/0098261X.2007.10767823

Zuieva, I. \& Prystup, V. (2019). Organizational and Legal Problems of the Development and Activitirs of the Ukrainian Jurisdictional Service. Juridical Scientific and Electronic Journal, 3, 238-243. Retrieved from: http://www.lsej.org.ua/3_2019/63.pdf 